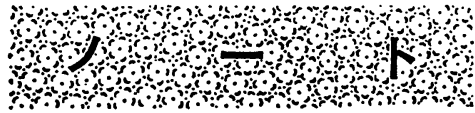

\title{
加熱気化-金アマルガム法による食品中の微量水銀の定量
}

(昭和 58 年 6 月 9 日受理)

$\begin{array}{ll}\text { 宮 永炤 一 } & \text { 林 } \quad \text { 哲生*1 } \\ \text { 角 昭美 } & \text { 浅野彦二*1 }\end{array}$

\section{Determination of Total Mercury in Foods by the Gold Amalgamation Method}

\author{
Shyoichi Miyanaga, Tetsuo Hayashi, Shyobi Kado and Hikoji Asano \\ (Hokuriku Public Health Laboratory: 1103, Koyo 4-chome, Fukui, Japan)
}

The gold amalgamation method to determine the total mercury content in various foods was examined in comparison with the wet digestion-reduction method. The results can be summarized as follows.

(1) In the case of the gold amalgamation method, the effect of moisture can be elim inated by covering the sample with cobalt oxide, and that of acids such as hydrochloric acid can be eliminated by the use of alkaline reagents according to method $\mathrm{C}$ (mixtures of calcium hydroxide and sodium carbonate, with cobalt oxide and activated alumina).

(2) The relationship between the values obtained by the wet digestion-reduction method $(\mathrm{X})$ and the gold amalgamation method $(\mathrm{Y})$ could be expressed as follows: $\mathrm{Y}=1.010$ $\mathrm{X}-1.344, \mathrm{r}=0.998$.

(3) The determination of trace amounts of mercury in various kinds of food samples, which is difficult by the wet digestion-reduction method, can be achieved satisfactorily by the gold amalgamation method.

(Received June 9, 1983)

Key words: 金アマルガム法 gold amalgamation method; 還元気化法 wet digestion-reduction method; 総水銀 total mercury

\section{緒言}

食品中の水銀定量法としては，厚生省通達（昭和48年 7 月23日，環乳第99号）による魚介類の総水銀の検査法 が公定法として定められている1)が，この方法は分解に 長時間を要し, しかも分解操作が繁雑であり, かつ定量 限度は食品で $10 \mathrm{ng} / \mathrm{g}$ と微量水銀を定量することは困 難である.

微量水銀の測定には金アマルガム-冷原子吸光法が 用 いられ，良好な結果が報告されている。この方法は，迅 速・簡便で短時間に多数の試料を分析できるなどの特長

*1 (財) 北陸公衆衛生研究所：福井市光陽 4-1,103
を有し，かつ定量限度が $0.1 \mathrm{ng} / \mathrm{g}$ と微量水銀の定量が 可能である2).

しかし, 還元気化法と比較すると精度及び正確さの点 でいくつかの問題が提起されている ${ }^{3)}$. その原因として， 検量線作成時及び 試料 $5^{5)}$ ＊2 へそれぞれ加える 添加剤の 加え方, 試料中の水分量及び加熱分解方法等2),6) 8) が影 響を及ぼしているのではないかと指摘されている.

著者らは，金アマルガム法による食品中の微量水銀の 測定に及ぼす諸条件を検討するとともに，還元気化法と

*2 水銀測定専用装置りガク・マーキュリー/SP テク ニカル・レポート (1979) 
の比較を行ったところ，若干の知見が得られたので報告 する。

\section{実 験方法}

\section{1. 試料}

玄米, 大豆, 緑茶, 乾燥ひじき, 乾燥わかめ, 牛肉, 身欠にしん，にぼし，イカ，ブリ，チカダイ及びハマチ を用い，玄米は直接農家から入手し，その他の試料は福 井県内で購入した.

\section{2. 試薬}

水銀標準液は和光純薬工業 (株) 製, 原子吸光分析用 を，L-システィン，塩酸ヒドロキシルアミン，尿素，塩 化第一スズ，水酸化カルシウム，無水炭酸ナトリウム及 び活性アルミナは和光純薬工業(株)製，特級を，硫酸及 び硝酸は和光純薬工業 (株) 製, 精密分析用を, 過マンガ ン酸カリウムは和光純薬工業 (株) 製, 有害金属測定用 を，酸化コバルトは半井化学工業(株)製を使用した。

水銀標準液は使用の都度, 適宜これを水銀希釈液で希 瑶して用いた．水銀希釈液は L-システィン $10 \mathrm{mg}$ を水 に溶かし，硝酸 $2 \mathrm{ml}$ を加え水で $1 \mathrm{~L}$ とし使用の都度， 調整した．金アマルガム用添加剂は水酸化カルシウム， 無水炭酸ナトリウム, 活性アルミナ及び酸化コバルトを それぞれ約 $800^{\circ}$ の電気炉で約 4 時間加熱処理したもの を用いた。使用に際しては，空試験值を測定し補正し た.

\section{3. 装置}

還元気化法には，日立製原子吸光光度計 518 型を用い た. 金アマルガム法には, 理学マーキューリー/SP 型を 用いた。

\section{4. 実験操 作}

\section{1 試料の前処理}

魚肉試料は，試料の 適当量をホモジナイザーで磨砕 し，小ガラスビンに入れ分析直前まで冷凍保存した．海 藻類及び植物試料は, $50^{\circ}$ で乾燥後粉砕し, 小ガラスビ ンに入れ保存した。

\section{2 還元気化法}

$500 \mathrm{ml}$ の丸底フラスコに試料 $1 \sim 5 \mathrm{~g}$ を科取し, 硫酸 $20 \mathrm{ml}$ と硝酸 $20 \sim 40 \mathrm{ml}$ を加え 2 時間加熱，放冷後更 に 6\% 過マンガン酸カリウム溶液 $20 \sim 40 \mathrm{ml}$ を加え 1 時間加熱・分解し，水で希釈し $100 \mathrm{ml}$ 定容とした。分 解液の一定量をとり水で $200 \mathrm{ml}$ とし, 硫酸 $(1+1) 5$ $\mathrm{ml}$ 及び $10 \%$ 塩化第一スズ溶液 $5 \mathrm{ml}$ を加え水銀を還元 気化し，水銀分析計で測定した，検量線は，水銀標準液 $(0 \sim 0.5 \mu \mathrm{g})$ について, 試料と同様に還元気化し作成し た.

\section{3 金アマルガム法}

試料 50〜200 mg をあらかじめ $800^{\circ}, 1$ 時間加熱処理 した磁製試料容器に科取し, Fig. 1 に示す方法に従い添 加剂を加え, 磁製試料容器を加熱炉に入れ水銀濃度を測 定した．加熱温度及び時間は，水銀標準溶液では $370^{\circ}$,
1 分間, $700^{\circ}, 4$ 分間, 試料では $370^{\circ}, 4$ 分間, $500^{\circ}, 4$ 分間, 又は $700^{\circ}, 6$ 分間, $900^{\circ}, 6$ 分間とした. 空気流量 は水銀標準溶液及び試料の加熱に際しては $0.5 \mathrm{~L} / \mathrm{min}$, 水銀第二捕集室より吸収セルへの導入に際しては 0.3 $\mathrm{L} / \mathrm{min}$ とした.

\section{実験結果及び考察}

\section{1. 金アマルカjム法の定量条件の検討}

\section{1 各種添加剤の加え方}

添加剤の加え方は Fig. 1 に示す通りである. 添加剤 としては活性アルミナ, 水酸化カルシウム, 酸化マグネ シウム及び炭酸ナトリウムなどが用いられており，活性 アルミナは試料を徐々にかつ均一に加熱する目的で，水 酸化カルシウム, 酸化マグネシウム及び炭酸ナトリウム は酸性ガスを吸収する目的で用いら机ている。一般に金 アマルガム法では, Fig. 1 に示す添加法A又はBが用い られている*2. また，試料を完全に扊化させるため酸化 触媒として酸化 コバルト ${ }^{9)}$ (10)の添加も検討されている. 本実験では, 添加法 A, B , C 及び D の 4 種類の方法に ついて比較検討した.

\section{2 水銀標準溶液に対する添加剤の影響}

水銀標準溶液に対する添加剤の影響を Table 1 に示 す. 平野 ${ }^{4)}$ は, 検量線作成時に添加剤として水酸化カル シウムを用いると，水銀の回収率が低下することを報告 している. 一方，添加剂を全く加えないことあるいは添 加剤の種類及びその加え方を工夫することにより回収率 の低下をきださないという報告もある5)*2. そこで 10 $\mathrm{ng} / \mathrm{ml}$ の水銀標準溶液を作り，この溶液 $1 \mathrm{ml}$ を磁製試 料容器にとり，添加剤を加えないで測定した場合と，添 加法 A 又は添加法 B の二種類の方法について加熱温度を 変化させ水銀の回収率を調べたところ，添加剤を加えな い場合，回収率は加熱温度にかかわらず 100\%であるの に対し，添加法Aの回収率は加熱温度 370 700 では 99.6\% であったが，添加法 B の回収率は加熱温度 370 〜 700 では 74.9\%，加熱温度 500 900 では 91.0\% であった.

以上のことから，水銀標準液を炭酸ナトリウム及び水 酸化カルシウムの混合物と接触させて加熱すると, 溶液 中の水銀の一部が炭酸ナトリウム及び水酸化カルシウム の混合物に捕捉され，一旦捕捉された水銀は装置内の気 化条件では気化しにくくなることが推察された．従っ て，水分含量の高い試料を添加法 B で測定すると，水銀 測定值が低くなる可能性が示唆された。

\section{3 各種添加法に対する酸の影響}

田中ら ${ }^{11)}$ は, 酸, 特に塩酸の存在は金アマルガムの生 成を妨害して負の誤差を与えるが，これらを中和して塩 として固定すれば妨害しないと報告している. そこで 各種添加法に対する 塩酸の 添加の影響を 調べた結果を Table 2 に示す. 添加剤を加えない場合, 添加法 A, C 及びDの水銀の回収率はそれぞれ $24 \% ， 93 \% ， 100 \%$ 及 
Table 1. Effect of Additives on the Determination of Standard Mercury

\begin{tabular}{llccccc}
\hline \hline $\begin{array}{c}\text { Method to use } \\
\text { additives }\end{array}$ & & $\mathrm{A}$ & $\mathrm{B}$ & $\mathrm{B}$ \\
\hline Temp. $\left({ }^{\circ} \mathrm{C}\right)$ & 1st step & $370,1 \mathrm{~min}$ & $370,4 \mathrm{~min}$ & $370,4 \mathrm{~min}$ & $500,1 \mathrm{~min}$ & $500,4 \mathrm{~min}$ \\
& 2nd step & $700,4 \mathrm{~min}$ & $700,6 \mathrm{~min}$ & $700,6 \mathrm{~min}$ & $900,4 \mathrm{~min}$ & $900,6 \mathrm{~min}$ \\
Hg added* (ng) & & 10 & 10 & 10 & 10 & 10 \\
Hg found $(\mathrm{ng})$ & 10.0 & 9.96 & 7.49 & 10.0 & 9.10 \\
Recovery & $(\%)$ & 100 & 99.6 & 74.9 & 100 & 91.0 \\
n & 5 & 5 & 5 & 5 & 5 \\
S.D. & 0.26 & 0.32 & 0.65 & 0.19 & 0.36 \\
C.V. & $(\%)$ & 2.6 & 3.2 & 8.7 & 1.9 & 4.0 \\
\hline
\end{tabular}

* Standard mercury solution: $10 \mathrm{ng} / \mathrm{ml}$

Table 2. Effect of Addition of Hydrochloric Acid on the Determination of Standard Mercury

\begin{tabular}{|c|c|c|c|c|c|}
\hline $0.5 \mathrm{~N} \mathrm{HCl}$ added $(\mathrm{ml})$ & 0 & 0.1 & 0.1 & 0.1 & 0.1 \\
\hline Method to use additives & & & A & $\mathrm{C}$ & $\mathrm{D}$ \\
\hline $\mathrm{Hg}$ added (ng) & 10 & 10 & 10 & 10 & 10 \\
\hline $\mathrm{Hg}$ found (ng) & 10.0 & 2.4 & 9.3 & 10.0 & 6.1 \\
\hline Recovery (\%) & 100 & 24 & 93 & 100 & 61 \\
\hline
\end{tabular}

Heating temperature: 1 st step $370^{\circ} \mathrm{C}-4 \mathrm{~min}, 2$ nd step $700^{\circ} \mathrm{C}-6 \mathrm{~min}$

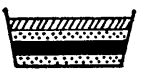

A.

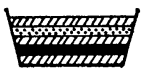

B

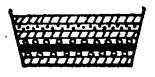

C

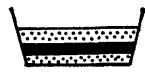

$\mathrm{D}$
: sample; $\quad$ alkali reageants $\left(\mathrm{Na}_{2} \mathrm{CO}_{3}: \mathrm{Ca}(\mathrm{OH})_{2}=1: 1\right)$

웅ㅇㅁ : cobalt oxide

Fig. 1. Methods of additives packing amounts of sample and additives

(A) sample, $50 \sim 200 \mathrm{mg} ; \mathrm{Al}_{2} \mathrm{O}_{3}, 2 \mathrm{~g}$; alkali reagents, $1 \mathrm{~g}$

(B) sample, 50 200 mg; $\mathrm{Al}_{2} \mathrm{O}_{3}, 1 \mathrm{~g}$; alkali reagents, $2 \mathrm{~g}$

(C) sample, 50 200 mg; $\mathrm{Al}_{2} \mathrm{O}_{3}, 1 \mathrm{~g}$; alkali reagents, $2 \mathrm{~g}$; cobalt oxide, $1 \mathrm{~g}$

(D) sample, $50 \sim 200 \mathrm{mg} ; \mathrm{Al}_{2} \mathrm{O}_{3}, 2 \mathrm{~g}$

び $61 \%$ を示した.

以上のことから，試料を炭酸ナトリウム及び水酸化カ ルシウムの混合物にはさみこみ測定すると，加熱時に発 生する酸性ガスを完全に吸収することがわかった，本装 置では, 塩酸のような酸性ガスは酸化促進炉内の酸化銅 を侵すため，水銀測定值に負の影響を与えるものと考劣 られた。

\section{4 加熱条件の影響}

4 種類の食品を用い添加法 B 及び C に対する加熱温 度の影響を調べた結果を Table 3 に示す. 添加法 B, 加熱温度 $370 \sim 700^{\circ}$ は，添加法 $\mathrm{C}$ ，加熱温度 $370 \sim 700^{\circ}$ に対し, 水銀測定值は全体に低い值を示した。添加法 B, 加熱温度 $500 \sim 900^{\circ}$ は添加法 C, 加熱温度 $370 \sim 700^{\circ}$
とほほとんど大差なかったが，添加法 B，加熱温度 500 〜900 では加熱温度が高いため 炭酸ナトリウムの一部 が融解し 固化する現象が認められた. なた本水銀気化 装置の加熱炉は $900^{\circ}$ の高温で使用すると劣化が顕著に なるといわれており，従って添加法 B の高温での使用は 添加荗の一部融解及び装置の劣化を考えた場合問題であ る.

\section{5 添加剤（酸化コバルト）の量の影響}

試料として身欠にしんを用い，試料 $100 \mathrm{mg}$ に酸化コ バルト量を $0.25 \sim 1.0 \mathrm{~g}$ とした場合，また酸化コバルト 量 $1 \mathrm{~g}$ に試料を 50〜200 mg とした場合の測定値の違い を検討した結果を Fig. 2 に示す. 試料を $100 \mathrm{mg}$ と一 定にした場合，酸化コバルト量 $0.25 〜 1 \mathrm{~g}$ の範囲ではほ

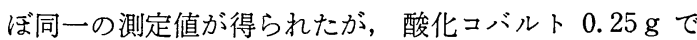
は変動係数が $8.7 \%$ と大きく, 酸化コバルト量は 0.5 ～ $1 \mathrm{~g}$ が適量と考えられた．酸化コバルト量を $1 \mathrm{~g}$ と一定 にし, 試料を $50 \sim 200 \mathrm{mg}$ と変化させた場合，水銀測定 值に差異はみられなかった。

\section{6 添加方法の検討}

一般に添加方法として, 水, 尿, 血液等の液体試料は 添加法 Aが用いられ，土壤，生物試料等は添加法 Bがよ く用いられている*2). しかし，この両法は酸性ガス及び 水分の影響を同時に除去できない欠点を有している．著 者らは，添加法 Cはこの影響を同時に除去でき，また酸 化コバルトの触媒効果により試料の完全然焼が可能であ ると考えた．そこで添加法 $\mathrm{B}$ と添加法 Cについて，魚肉 6 種類, 肉類 1 種類, 海藻類 2 種類及び植物性試料 3 種 類, 計 12 種類の試料を用い比較検討した結果をTable 4 に示す. 各試料の水銀濃度を比較すると, 6 種類では添 
Table 3. Effect of Heating Temperature on the Determination of Mercury in the Food Samples

\begin{tabular}{|c|c|c|c|c|c|c|}
\hline Sample & $\begin{array}{l}\text { Method to use } \\
\text { additives }\end{array}$ & $\begin{array}{c}\text { Heating } \\
\text { temperature } \\
\left({ }^{\circ} \mathrm{C}\right)\end{array}$ & $\mathrm{n}$ & $\begin{array}{l}\text { Average } \\
\text { (ng/g) }\end{array}$ & S.D. & $\begin{array}{l}\text { C.V. } \\
(\%)\end{array}$ \\
\hline \multirow[t]{3}{*}{ Brown rice } & $\mathrm{B}$ & $370-700$ & 3 & 7.7 & 0.58 & 7.6 \\
\hline & $\mathrm{B}$ & $500-900$ & 3 & 8.3 & 0.58 & 6.9 \\
\hline & $\mathrm{C}$ & $370-700$ & 3 & 8.7 & 0.58 & 6.7 \\
\hline \multirow[t]{3}{*}{ Green tea } & B & $370-700$ & 5 & 10.2 & 0.45 & 4.4 \\
\hline & B & $500-900$ & 5 & 11.4 & 0.55 & 4.8 \\
\hline & $\mathrm{C}$ & $370-700$ & 3 & 11.8 & 0.58 & 4.9 \\
\hline \multirow[t]{3}{*}{ Dried herring } & B & $370-700$ & 3 & 37.5 & 0.55 & 1.5 \\
\hline & $\mathrm{B}$ & $500-900$ & 3 & 42.1 & 1.9 & 4.5 \\
\hline & $\mathrm{C}$ & $370-700$ & 3 & 41.2 & 1.6 & 3.9 \\
\hline \multirow[t]{3}{*}{ Immature yellowtail } & B & $370-700$ & 3 & 95.0 & 2.0 & 2.1 \\
\hline & $\mathrm{B}$ & $500-900$ & 3 & 95.3 & 3.1 & 3.2 \\
\hline & $\mathrm{C}$ & $370-700$ & 5 & 96.6 & 2.6 & 2.7 \\
\hline
\end{tabular}
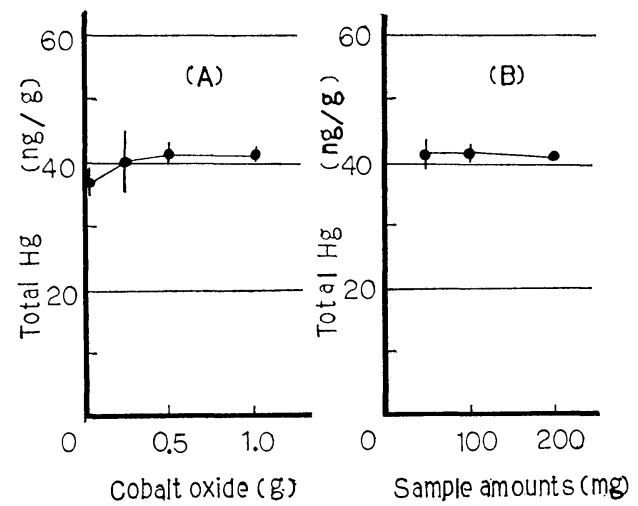

Fig. 2. Effect of amounts of cobalt oxide and sample on the total amounts of mercury

(A) sample, $100 \mathrm{mg}$; cobalt oxide, $0.25 \sim$ $1 \mathrm{~g}$

(B) sample, 50 200 mg; cobalt oxide, $1 \mathrm{~g}$

加法 B と添加法 Cでは大差なかったが，3 試料では添加 法 Cの方が添加法 $\mathrm{B} よ り$ 平均值が高く，また残りの 3 試 料では添加法 B と添加法 Cで明らかに有意差がみられ， 添加法 Cの方が添加法 B より高い值を示した．以上のこ とから，食品の水銀分析には添加法 Bより添加法 Cが適 していると考えられた.

\section{2. 還元気化法と金アマルガム法の比較}

水銀濃度が $10 \mathrm{ppb}$ 以上の魚肉 7 試料, 海藻類 1 試料, 計 8 試料について還元気化法と金アマルガム法の比較検 討を行った．その結果は Fig. 3 に示す通りである. 金 アマルガム法の添加法はCである．還元気化法の数值を $\mathrm{X}$, 金アマルガム法の数值を $\mathrm{Y}$ とし, 両者の関係式を求 めた結果, $\mathrm{Y}=1.010 \mathrm{X}-1.344$, 相関係数 0.998 が得ら れた。両者の分析精度を变動係数でみると，還元気化

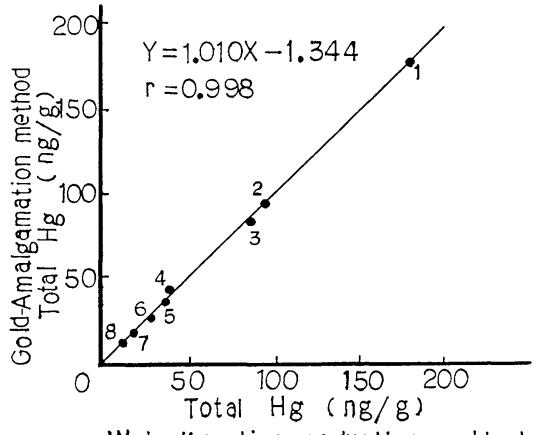

Wet digestion reduction method

Fig. 3. Comparison of total mercury determined by the wet digestion-reduction method and the gold amalgamation method in various food samples 1, octopus; 2, immature yellowtail; 3 , yellowtail; 4, dried herring; 5 , squid; 6 , dried sardines; 7 , dried wakame; 8 , sea breams

法では 3.9 8.0\%，金アマルガム法では $2.7 \sim 9.9 \%$ で両者の精度には有意な差はなかった。水銀濃度が 10 $\mathrm{ppb}$ 未満の試料についてみると, 還元気化法では定量限 界以下であるが，金アマルガム法では $1 \mathrm{ppb}$ 以上の試料 の測定が可能であり測定值のバラッキる小さかった.

\section{要 約}

加熱気化一金アマルガム法による 食品中の 微量水銀の 測定に及ぼす諸条件を検討するとともに，還元気化法と の比較を行った.

1）添加法 C，すなわち試料を酸化コバルト及びアル カリ剤ではさみこむ添加法は, 試料より発生する酸性ガ スの影響を完全に除去できるのみならず, 試料が酸化ュ バルトで覆われているため, 水分の影響も除去でき，ま 
Table 4. Comparison of Mercury Analysis between the Two Methods of Additives Packing (Method B and Method C) in Various Food Samples

\begin{tabular}{|c|c|c|c|c|c|c|c|c|}
\hline \multirow[b]{2}{*}{ Sample } & \multicolumn{4}{|c|}{ Method B } & \multicolumn{4}{|c|}{ Method C } \\
\hline & $\mathrm{n}$ & $\begin{array}{c}\text { Average } \\
(\mathrm{ng} / \mathrm{g})\end{array}$ & S.D. & $\begin{array}{l}\text { C.V. } \\
(\%)\end{array}$ & $\mathrm{n}$ & $\begin{array}{c}\text { Average } \\
\text { (ng/g) }\end{array}$ & S.D. & $\begin{array}{l}\text { C.V. } \\
(\%)\end{array}$ \\
\hline Brown rice & 3 & 7.7 & 0.58 & 7.6 & 3 & 8.7 & 0.58 & 6.6 \\
\hline Soybean & 3 & 5.0 & 0 & 0 & 3 & 5.3 & 0.58 & 11 \\
\hline Green tea & 5 & 10.2 & 0.45 & 4.4 & 5 & 11.8 & 0.45 & 3.8 \\
\hline Dried hijiki & 3 & 25.7 & 2.5 & 9.7 & 3 & 25.3 & 0.58 & 2.3 \\
\hline Dried wakame & 3 & 9.3 & 1.1 & 12 & 3 & 14.3 & 1.2 & 8.4 \\
\hline Beef & 3 & 4.7 & 1.2 & 25 & 3 & 5.7 & 0.58 & 10 \\
\hline Dried herring & 6 & 37.5 & 0.55 & 1.5 & 5 & 41.2 & 1.6 & 3.9 \\
\hline Squid & 3 & 35.7 & 1.5 & 4.2 & 3 & 36.3 & 1.5 & 4. 1 \\
\hline Dried sardines & 3 & 26.7 & 1.5 & 5.7 & 3 & 29.0 & 2.0 & 6.9 \\
\hline Yellowtail & 3 & 77.0 & 3.0 & 3.9 & 3 & 80.7 & 3.1 & 3.8 \\
\hline Sea breams & 3 & 17.7 & 2.5 & 14 & 3 & 17.7 & 1.5 & 8. 6 \\
\hline Immature & 3 & 95.5 & 2.5 & 2.7 & 3 & 96.6 & 2.6 & 2.7 \\
\hline Yellowtail & & & & & & & & \\
\hline
\end{tabular}

た測定の再現性も良好であった.

2) 還元気化法の定量值 $(X)$ と金アマルガム法のそ れ $(\mathrm{Y})$ との間には, $\mathrm{Y}=1.010 \mathrm{X}-1.344$ の関係式が得 られ, 相関係数は 0.998 であった. 变動係数は, 前者が $3.9 \sim 8.0 \%$, 後者は $2.7 \sim 9.9 \%$ で両者の精度に有意な 差はなかった. 水銀濃度が $10 \mathrm{ppb}$ 未満の試料について みると，還元気化法では定量限界以下であるが，金アマ ルガム法では $1 \mathrm{ppb}$ 以上の試料の測定が可能であり, 測定值のバラッキも小さかった.

なお, 本研究の要旨は日本食品衛生学会第45回学術講 演会（昭和58年 5 月，東京）で発表した.

終りに，本研究について論文のご校閲を賜った東京大 学農学部熊沢喜久雄教授に心から感謝の意を表します.

文献

1) 厚生省環境衛生局長通達（昭和 48 年 7 月 23 日 環乳第 99 号).

2) 中島秀治, 越野正義: 農技研肥料化学課資料第 239 号, 14〜54 (1982).
3) 田口正, 保田健二, 土器屋由紀子, 清水 誠, 戸田昭三：分析化学 26，496４98 (1977).

4) 平野 譲：新潟公害研報告. 6, 22 26 (1981).

5) 内川 浩, 古田力久, 三原康央: 分析化学 31,367 $\sim 372$ (1982).

6)牧野和夫, 桐田久利子, 相平伸幸, 渡部欣愛：環 境と測定技術 9，40４8（1982）.

7) 安部美津子, 新倉信子：分析化学 $29, T 5 \sim T 9$ (1982).

8) 白井文雄, 藤田昌彦, 岩島 清：食衛誌。 24,52 $\sim 56$ (1983).

9) 辻野隆三, 上田貞夫, 森田武憲: 分析化学 22, 591 593 (1973).

10）田中之雄, 池辺克彦, 田中凉一, 国田信治：食衛 誌. 15, 386〜389 (1974).

11）田中克彦, 深谷勝久, 福井昭三, 菅野三郎：衛生 化学 20,344 348 (1974). 